\title{
The Effects of Web-Based Technologies on Marketing Activities of Professional Sports Clubs
}

\author{
Serdar Samur (Corresponding Author) \\ Department of Sports Management, Sports Science Faculty \\ Gedik University, Istanbul, Turkey \\ E-mail: ssamur_2002@yahoo.com
}

Received: May 15, 2021 Accepted: June 11, 2021 Published: June 25, 2021

doi:10.5296/jei.v7i1.18651 URL: https://doi.org/10.5296/jei.v7i1.18651

\begin{abstract}
The global market's economic growth has been boosted by the size of the sports industry, which now has a budget in the billions of dollars. Sports marketing has emerged as a result of this growth in the sports industry. Sports marketing has emerged as the most important feature of sports companies, having grown in importance as a scientific discipline. Inside the industry, sports clubs have started to search for ways to increase their market share in both national, and foreign markets. The industry's ongoing growth has resulted in an increase in the number of goods, and services available, as well as a competitive climate. The purpose of this study is to identify innovations in web-based technology used by sports clubs to market their goods, and services to target audiences. The research was carried out in accordance with the standards of qualitative research. Search engines, blogs, forums, podcasts, press bulletins, e-mail, and content sharing sites are the most commonly used web-based technologies by sports clubs, according to the results of the study.
\end{abstract}

Keyword: Web based technologies, Marketing, Digital media, Social media, Sports club

\section{Introduction}

Since the last 1990s, the sports industry has shown a great development, and change all over the world.The presence of sports businesses, companies producing sports goods, sports facilities, stadiums, players, and professional leagues in the industry has provided the growth of sub-sectors.

This development in the sports industry has made sports marketing an important discipline in the scientific world. Sports organizations in the market have also begun to look for ways to get a larger share in both national, and international markets. 


\section{Macrothink}

The continuous development of the sports industry has increased the number of sports businesses, and their products, and created a strong competitive environment. Sports marketing activities of sports clubs have become important in to keep up with the rapid changes in the market. Facing with a large number of competitors, sports businesses use sports marketing as the most important function of their businesses.

Since the 2000s, the rapid change in technology, the increase in the internet, and social media has started to move the marketing activity away from its traditional structure.

We live in a digital era, which has resulted in the growth of internet-based marketing activities for companies. Businesses use the internet for four purposes. The widespread use of the internet, the transparency of the supply chain, customer relations, and communication-branding campaigns are all examples of these (Rohm \& Sultan, 2004).

The increase in internet usage in our country will also increase the marketing activities to be carried out in the internet environment. According to the report of the Turkish statistical agency, household internet use was $18.8 \%$ in 2004 , while this rate is $79 \%$ today. This rate of change causes sports clubs to adopt new marketing approaches.

This study was conducted to assess the application areas of modern web-based technologies and social media for sports marketing, which are among the issues where sports clubs can gain a competitive edge in the digitalized world.

\section{Literature Review}

Marketing is one of the most important, and complex functions for sports organizations. Sports organizations have the opportunity to promote, and sell their products through their marketing efforts (Parks, Zanger, \& Quarterman, 1998).

Sports Marketing is the process that includes the organization, and implementation of activities necessary for the production, pricing, distribution, and promotion of a sports product in order to achieve the goals of the business, and to satisfy the demands, and needs of the consumers (Pitts \& Stotlar, 2013).

Sports Marketing should be considered as a concept that includes sales, advertising, and public relations activities (Argan \& Katırc1, 2020). In sports marketing; There are 3 methods: Marketing of Sports Products,Marketing Sports Products, and Marketing Through Sports (Kocabas, 2005).

Marketing of Sports Products: there are goods such as jerseys, and tracksuits with Club colors, scarves, flags, caps, crafts and perfumes. Travels organized by the clubs for their matches in European Cups are also considered within this scope (Samur, 2017). Sports Marketers produce, distribute, and promote products that both athletes, and consumers will need. It is the encouragement of spectators interested in sports to participate in these activities in order to increase the consumption of sports events (League match etc.) (Mullin, Hardy, \& Sutton, 1993).

Marketing Through Sports: Marketing of industrial goods, and services to consumers by 
using sport is defined as commercial firms using sport as a marketing communication tool for the promotion of their products. The best example of marketing through the use of sports as a tool is sponsorship, and license agreements (Argan \& Katırc1, 2020).

Today, Web based communications has become important for sports clubs to deliver their goods, and services to consumers. While the technologies take a variety of names, they all provide a way for people to express their opinions. The most important features that enable the internet to be used as an effective, and efficient online marketing tool are that it is an interactive communication tool, and allows one-to-one marketing.

Direct Marketing is not an open marketing technique for everyone. It is used to establish a one-to-one relationship with the target audience. While its cost is lower than mass marketing, interactive communication increases the effectiveness of marketing activities (Özmen, 2003).

Internet has gained an important place in marketing, as in many other areas, thanks to its fast access, and flexible usability possibilities.In the most general sense, on-line marketing efforts made on the internet are called e-marketing. In other words, e-marketing; It is the use of internet, and digital technologies related to the internet to achieve marketing goals (Kocabaş, 2005).

In the digitalize world, digital marketing has become a medium that many companies should adapt to. Online marketing is both the right way to reach customers, and an area where competition is very high. Digital Marketing offers very strong interaction opportunities with the target audience. It can direct your potential customers directly to the sales interface, to your product on your e-commerce website. Digital marketing tools increase the awareness of companies, and contribute to the measurement of campaigns, and the analysis of the result and process.

Social Media marketing is used as a part of integrated marketing communication. Businesses provide links to their websites to integrate their websites, and social media accounts (Facebook, Twitter, Instagram, LinkedIn). This integration of businesses is important for search engine optimization (Kircova \& Enginkaya, 2015). Businesses that carry out marketing activities on Social Media have the opportunity to reach more customers, persuade their customers, develop better products, and faster feedback (Ryan, 2016).

Social media provides active participation in the form of communicating, creating, combining, collaborating, working, sharing, socializing, buying, selling, and learning in interactive, and interconnected networks. Social media refers to the use of social media technologies-channels, and software to create, communicate, present, and exchange offers that have value for an organization's stakeholders (Tuten and Solomon).

Social Media Marketing means the use of social media as a marketing tool exclusively, and can operate in three different areas such as Public Relations, Content Marketing, Viral Advertising and Messaging (Miletsky, 2009).

One of the most important ways to catch up with the customer in marketing is to reach the customer with content. Among the various marketing techniques used in the digital world in 
the internet environment, there are Search Engines, Web site/Mobile sites, Forums, Blogs, Podcast, Press Bulletins, E-mail groups, Content sharing sites, and platforms (Kocabaş, 2015; Scott, 2010; Bala \& Verma, 2018).

\subsection{Search Engines}

It is a technique that provides relevant content for searchers to be presented in the search list, encourages searchers to go to the targeted site, and allows them to reach their goals by highlighting the business through search engines (Chaffey \& Ellis-Chadwick, 2012). Search engines bring the products or services sold by businesses to the potential customers when they are searched (Ryan, 2016). Search engine marketing is to reach the target audience directly by using search engines (Scott, 2007). Search engine marketing is a form of internet marketing where websites are promoted by increasing their visibility through optimization or advertising on search engine results pages (Sullivan, 2007).

\subsection{Website}

A great website is the crossroads of all online initiatives, including podcasts, blogs, press releases, and other online tools. Proper colors, fonts, and design make the site attractive (Scott, 2010). The advantages of website applications for businesses can be listed as follows: (Gules et al., 2003).

- Active use of the website offers businesses the opportunity to run their business activities 24 hours a day.

- Web site applications provide businesses the opportunity to globalize economically, and technologically by removing geographical boundaries.

- As web applications offer personalized sales opportunities, they ensure the establishment of a special bond between customers, and businesses, and the development of customer loyalty.

- The sales model on the website provides rapid access to target markets without making large investments.

- Web applications can be in the form of gaining new customers from many sources or increasing transaction volume with existing customers.

- Doing business online provides companies with a wealth of branding and personalization opportunities. Consumer loyalty, and customer retention are boosted by both factors.

- It provides businesses with the opportunity to obtain the inputs they need in the production process from the most appropriate sources.

- All kinds of information about products, services, and the company can be presented to visitors by means of audio, video, and photographs that can be placed on web pages. (Mehmood et al., 2017).

- Reduces misunderstandings, and errors that may arise in commercial transactions. 


\subsection{Participation in Forums}

They are sites that exchange ideas, and information according to special interests (Söylemez \& Kayabas1, 2020). Businesses can attract the attention of special interest groups by participating in such formations or by sponsoring them. Many forums are supported by interest groups (Kocabas, 2015). Just showing up in blogs, forums, and chat rooms that your customers frequent shows that you care for these people. The linking feature of the Internet will allow participants who see your posts in a forum or blog to reach there from other forums, and blogs (Scott, 2010). Participants of discussion forums, where people have a common bond, feel the forums belong to them. People representing companies need to come to the forum to make them feel that they value other participants (Scott, 2010).

\subsection{Blog Publishing}

The blog, which means "web diary", is an internet-based, target audience priority news dissemination, and public relations tool that emphasizes mutual interaction with target audiences (Yavuz \& Haseki, 2012). Blog users generally send regular comments, and posts containing text, graphics, videos, or links to other blogs, and websites, usually in chronological order (Close, 2012).

The power of weblogs is that they allow millions of people to easily publish their own thoughts, and comment on them for millions (Tyson, 2012). Blogs have made it so easy for people to communicate their thoughts to the world that everyone can now publish their own ideas (Sterne, 2010).

Organizations use blogs to understand what stakeholders are doing, and measure their corporate reputation. Reputation management is important, and media measurement is an important part of the work of PR employees (Scot, 2010).

Customers' buying decisions are influenced by blogs. Blogging is the most effective form of content marketing, according to $37 \%$ of marketers. Blogs are read by 77 percent of Internet users. 81 percent of consumers in the United States depend on blogs for advice and facts. Blogs are used by B2B marketing specialists to pull in 67 percent more new clients (Source: http://www.quicksprout.com).

\subsection{Podcast}

Podcasting is a social media component that enables the distribution of digital voices over the internet through individuals' computers or portable media (Gonenli \& Hurmeriç, 2012).

Podcasts have become the most used digital marketing tool that has emerged in recent years, and brings the brand, and the public together (http://www.corazu.com).

Typically pod casters provide regular updates on their content for viewers such as video bloggers to consume. The contents are generally provided via audio for the subscribers to connect, and influence, and the possibility to download via iTunes is available (Akar, 2010).

With podcasting, people can immediately liberate themselves from broadcast hit-driven radio broadcasts, and listen to the programs they choose according to their particular interests 
(Scott, 2010).

Marketing professionals have a tool to effectively create audio content, and communicate it to those who want to buy it. The podcast is an increasingly important part of the marketing mix as a component of a comprehensive content marketing strategy (Rowles \& Rogers, 2015).

For many organizations, marketing podcasts are used as a marketing strategy in conjunction with blog posts, a great website, e-books, and other online marketing tools and programs (Scott, 2010).

\subsection{Press Releases}

Along with websites, online press releases are one of the most used Internet-based applications by public relations experts (Heath \& Coombs, 2006). Kelleher (2007) states that online press releases can be a useful tool in spreading information to relevant target audiences.

Press releases targeted directly at the consumer are an important component of the marketing mix. The media still gets some of their content from press releases. Millions of people read press releases directly from the source, without being filtered by the media (Scott, 2010). Newsworthy press releases are written by news agencies, editors, and distributed to large audiences.

\subsection{Email Lists and Groups}

They are mails that contain a sales text, and a call to action that businesses send to their customer list (Ryan, 2016). In e-mail marketing, an e-mail list is primarily created. Products, and campaigns are prepared in line with the wishes, and needs of the customers on this list (Penpece, 2013).

Creating a list of the target audience (age, gender, city, etc.), and separating them into groups will be effective. Getting detailed information during the registration of the mailing list to the database will be useful for the campaigns (Ryan, 2016). Email groups are a method used by like-minded people to connect with each other, just like forums (Scott, 2010).

\subsection{Content Sharing Sites}

It is a video sharing website hosting millions of videos in YouTube content. In addition, it is a social media tool where businesses can upload their own promotional videos, publish their advertisements, and provide customer satisfaction, and loyalty by responding instantly according to the comments, and opinions received by the click rate (Sin, Nor, \& Al-agaga, 2012).

Facebook: It offers the opportunity to communicate, and connect with the target audience. Facebook, which has become the world's largest social network with the participation of nearly a million new people every day, offers services under three headings as individual profiles, groups and pages (Kerpen, 2011).

Facebook is a social networking site that can be used in various ways as a marketing tool. 


\section{Ml Macrothink}

Companies can be friends with Facebook members, and send them a private message on any event or important topic (Schmidt \& Ralph, 2011).

LinkedIn: It is one of the social networks that can be preferred in terms of reflecting the potential of the individual or the enterprise, and at the same time, where productivity can be revealed. On the other hand, it provides an environment where the business can be promoted, and the people interested in the business can be reached directly, and strategies that will affect the sales can be developed (Yavuz \& Haseki, 2012).

Twitter: With its features, it has the opportunity to develop marketing, brand strengthening, establish new customer, and business connections, analyze the activities of competitors, and follow popular topics, especially for businesses (Altuğ \& Özhan, 2018). Twitter is an ideal tool for businesses for listening to audiences, two-way communication, content sharing, developing, and maintaining relationships.

Through such a channel, the target audience of the enterprises is informed very quickly about the activities, products, services of the enterprises, and after-sales support activities. This increases the traffic of marketing activities, and relationship building activities (Yavuz \& Haseki, 2012). It is possible to create followers, exchange information, and short promotions about the product to be sold (Sin, Nor, \& Al-agaga, 2012).

\section{Research Methodology}

\subsection{Limitations}

This research is limited to 5 clubs selected from 1 st league, and super league sports clubs in Turkey.

\subsection{Participants}

It was attempted to ensure that the participants are men and/or women who have worked in the sports club marketing department as advertising and marketing specialists for at least 5 years. There is no upper age limit. The number of participants ranges from one to five.

\subsection{Design of Research}

The participants were interviewed in the sports club's administrative buildings. The research was conducted in a qualitative design. In qualitative research, qualitative data collection methods such as observation, interview, and document analysis, perception and events are tried to be presented in a realistic and holistic manner in the natural environment (Y1ldirım \& Simsek, 2005).

\subsection{Development of Data Collection Tool}

The data were collected by interview techniques with experienced people in the club marketing unit. In the interview with individuals, a semi-structured main question, and a sub-question related to it were asked, and the data were evaluated accordingly. In the interviews, only one question was asked. The first question was enlarged with a sub-question if it was determined that the participants did not mention the use of social media throughout 
their responses to the inquiry.

\subsection{Interview Technique and Questions}

The participants were given preliminary information about the purpose and method of the research and the principles of the interview. Patton's interview form approach was used as the interview technique.

The participants were interviewed at their own offices and the interviews lasted around an hour. During the interviews, voice recordings were made with the participant's consent. The question, and sub-question in the interview form are as follows:

- Basic Question: Which of the web-based communications do you use for Sports marketing in the change in Internet technologies? Why is that?

- Sub-question: What platforms do you use for your social media usage?

\subsection{Data Analysis}

The data were first written by the researcher in computerized form and then analyzed by using content analysis from qualitative research techniques. The answers given by the department managers to each question were grouped in terms of their similarities, in order to increase the reliability of the study, an expert's analyzes were taken into consideration and common points were determined.

\section{Results}

Marketing has evolved from a one-way intervention from the institution to the target audience to a business of presenting material precisely when the target audience requires it. Marketing has expanded to include advertising and rights management. Today, although the advertising activity remains as a field in marketing, the field that it limits in terms of marketing has been confirmed by the literature. It is explained that marketing is not just about advertising, it is the common view of all participants.

On the other hand, public relations (PR) has expanded beyond the traditional media audience. The target audience for public relations is customers who come across your business on the internet. There is no clear line between internet marketing, and public relations.

You are now recognized for what you have, and share in the digital age. We are living in a time when people prefer reality to opinions, and engagement to propaganda.

If a work can't be produced as a result of marketing activity, it's not marketing. With great online content, businesses are beginning to draw customers to their buying process. Buyers will tell you know your stuff if you have well-edited, excellent material.

Organizations may connect directly with customers through blogs, podcasts, e-books, press releases, and other forms of online material. Regulations are made within the general marketing strategies of sports clubs to attract wider audiences, and supporters who do not obtain adequate service through the internet. 
In marketing, it would be necessary to thoroughly examine buyers, and construct formal buyer categories based on the demographic constructs of the target audience.

It would be easier to produce content that addresses each demographic group if we split the consumers into different categories. We will build a partnership based on confidence if we concentrate on the issues of the fan community and create content in this direction.

On the internal pages of the website, information that will cater to the fan base defining the product, and service on digital platforms must be provided with appropriate material. The sports club will begin to clarify the possible solutions found once it has established an online relationship with its fan base.

Your visitors will be guided through the sales cycle by well-organized site content before they are ready to make a purchase or enter into another partnership with your company.

Understanding consumers, and developing an effective marketing strategy to reach them is vital to success, as are the ties that connect content to the action.

Employees in marketing are now knowledge suppliers. As a valuable commodity, they must handle content on specific topics. Marketers can start with a content strategy, and then concentrate on the mechanical, and acceptable design requirements by selecting a digital platform for delivering that content.

When done correctly, social media marketing can create more fans-customers, traffic, and conversions, and can be a powerful channel for taking the company to the next level.

Social media provides an opportunity to establish, maintain, and strengthen social, and professional relationships with businesses. Marketers must strive to establish mutually satisfactory long-term relationships with key fans, including customers.

First of all, content that focuses on important issues in accordance with the company goals must turn into business goals defined in a way that will enable people to take action. The content prepared from now on is expected to engage the visitors in the sales thinking process, and then guide them to the place where the action took place. In this method, the purpose is clear, not confidential, and makes it easier for customers to find their way to the next step.

It is necessary to work on the issues that have become business targets to reach all stakeholders through search engines, press releases, forums, podcast broadcasts, blogs, e-mail groups, content sharing sites, which are among web-based websites, and social media platforms. The benefits of these are as follows:

\subsection{Search Engine}

With search engine marketing activities, it will be appropriate for sports clubs to organize their websites according to the structure of the search engine (optimize) or to target to rise to the top of the search engine results pages by advertising to the search engine. In this way, it will be easier for them to increase their visibility, and awareness towards the fans, spectators, and customers they target. 
Fans generally use the search engine to find information on the internet. In this context, users seeking information on the subjects that sports clubs serve constitute the target audience of the business. For this reason, the club can directly communicate with its target audience through a successful search engine marketing process.

\subsection{Web Sites}

Internet has become a strong communication, shopping, and advertising channel for sports clubs that enter every field of daily life. Sports clubs' websites are the main source of access to other social media platforms.

The website of sports clubs is also the gateway of the club to the outside world. The website has become one of the most important digital marketing tools that can be used to gain more traffic or to make more sales. The e-commerce of fan merchandising is also the main source of information that websites are directed.

\subsection{Press Releases}

Sports clubs need platforms that will provide direct information flow with their fans. An effective press release increases visibility in the press, and ensures that products, and services are advertised, and promoted free of charge on trusted sources.

Today, when competition is intense and information pollution is increasing, it becomes important to be known with real news in order to prevent biased publications by the press, and to draw attention to the brand.

Reliability is important. Press releases should be used frequently to improve the media in favor of the club. Including the club brand name in the headlines of the written press is necessary to increase reputation in marketing, and promotion activities. The club must be addressing stakeholders directly

Your main target audience is no longer just a journalist group. The target audience is millions of people who have internet connections, and use search engines. It is important to reach them, and attract them to the club.

\subsection{Forums}

Sports club marketing officers need to actively participate in online groups with fans important to their market. If you have something to sell or have comments about your product or service, this is the right place.

Sports club marketing staff can enter the forums, and offer ideas, and advice about their knowledge, which can make them active participants of the group. After that, orientation will be easier for the purpose.

\subsection{Podcast Broadcasts}

Podcast have opened up a new area for sports clubs. It would be appropriate to use podcasts that do not require additional cost to make the brands of the clubs known, and different. Podcasts included in the mobile compatible application have become important for the sports 
club to create public relations, and customer satisfaction.

Podcasts for the club as a brand should be used in an interactive marketing strategy to reach new customers, and listen to their views. In order to reach the young fans of the clubs, and to spread the messages through them to a wide audience, the Pod broadcast can be listened to from an iPod or any other MP3 player, as well as from smart phones, and computers.

\section{6 Blogs}

Blog for sports clubs is one of the most informal communication, and marketing methods for social networking. Corporate blogs, which contain content that attracts the attention of fans, and spectators, and affect purchasing decisions, are shared on social media channels, and spread rapidly to a wider area.

It will be beneficial to use blogs as independent news channels that contain opinions on every subject related to sports. Clubs see Blogs as a market intelligence resource. It is necessary to pay attention to the issues that the club will convey to the fans, rather than their expectations, and problems. Blogs should not be a sales channel, but a referral position that affects it.

\subsection{E-mail and Groups}

Electronic marketing, one of the direct marketing techniques, has been an important method of communicating with the fans. In e-mail marketing, relevant- more effective messages can be personalized.

\subsection{Content Sharing Sites}

Sports clubs are also non-governmental organizations. Content sharing sites, and platforms include sharing, uploading, and interpreting all kinds of media such as content sharing, images, videos, audio files, and games.

It is necessary to see content sharing sites as an interactive process that includes activities such as instant message transmission, and link sharing to the fans on websites or blogs. Content sharing accompanied by social comments to the shared content, and providing a two-way communication opportunity that requires the participation of the sender, and the receiver provides the club with a feed back facility.

YouTube, Facebook, LinkedIn, and Twitter, which are among the content sharing sites, and social media platforms, are seen as important in terms of adapting to the digital world due to their increase in the interaction with the fans, and their direct contribution to the marketing activities.

\section{Finding}

Codes and themes defining the web-based technological innovations used by sports clubs for marketing goods and services are given in Table 1. 
Table 1. Codes and themes of web technologies used in sports marketing

\begin{tabular}{|l|l|l|l|}
\hline Questions & Code & Theme & Participants \\
\hline $\begin{array}{l}\text { Basic Question: Which of } \\
\text { the changes in internet }\end{array}$ & -Information,participation & 1. Search Engines & $1,2,3,4,5$ \\
technologies and web-based & -Editing and directing & 3. Forums & \\
communications do you use & content & 4. Blogs & \\
for Sports marketing? Why & - Promoting the sale & 5. Podcast & \\
is that? & - Effective communication & 6. Press Releases & \\
Sub Question: & and rapid deployment & 7. E-mail and Groups & \\
Which platforms do you use & -Fast access, flexible & 8. Content sharing sites & \\
for social media usage? & availability and routing & & \\
& - Less cost more visibility & & \\
& -Doing a lot of work with & & \\
& few resources & & \\
\end{tabular}

The following are the statements of the research participants, as well as the analysis based on the claims and opinions of the authors in the area literature.

\subsection{Theme 1: Search Engines}

Participants $(1,4)$ see search engines as a means of reaching fans, and viewers. Scott (2007) says that search engine marketing provides direct access to the target audience using search engines. Ryan (2016) claims that search engines bring businesses to potential customers at the exact moment they search for their products or services.

Participants $(2,5)$ say sports clubs should organize their websites according to the structure of the search engine in order to reach their fans and their audience, to increase their visibility and awareness, to create a new audience. Chaffey and Ellis-Chadwick (2012) state that it is a technique that provides the relevant content for search engine searchers to be presented in the search list, encourages searchers to go to the targeted site, and highlights the business through search engines, allowing them to reach their goals.

Participants $(1,3,4)$ believe that the sports club should aim to rank high on the results pages of the search engine by advertising on the search engine about the fan products, and services newly released. Sullivan (2007) claims that search engine marketing is a form of internet marketing where websites are promoted by increasing their visibility through optimization or advertising on search engine results pages.

The statements of the participants are close to the thoughts of the authors.

\subsection{Theme 2: Website}

Participants $(1,3)$ state that a well-defined, and designed website creates the most suitable 
environment for blogs, podcasts, and press releases, and is the main source of information. Mehmood et al. (2017) states that all kinds of information about products, services, and the company can be presented to visitors through audio, video, photographs that can be placed on web pages. Scott (2010) claims that a great website is the crossroads of all online initiatives, including podcasts, blogs, press releases, and other online tools.

Participants $(2,4)$ state that it is possible to mobilize the fan base by organizing and managing website content. In addition, the participants state that producing quality content for the fan base makes the site a zest, and a stopover point. Guleş (2003) states that as Web applications offer personalized sales opportunities, they ensure a special bond between customers, and businesses, and the development of customer loyalty. Additionally, Guleş (2003) claims that web applications will contribute to businesses by gaining new customers from many sources or increasing transaction volume with existing customers.

The participant $(1,4)$ states that in order to reach the fan base via the internet according to the marketing plan, it is necessary to group them according to their specific characteristics, and additionally, after grouping the target audience according to their characteristics, it is necessary to make a marketing program. Gules (2002) states that doing business in electronic environment in accordance with the characteristics of the target audience offers great opportunities to businesses in branding, and personalization. Both of these factors have positive effects on consumer loyalty and customer satisfaction.

The Participants $(4,5)$ say that it would be beneficial to be in communication using all kinds of media, and to influence all kinds of issues that affect the decision-making processes of the buyers in order to have information about the Buyers. After determining the characteristics of the receiver, it is necessary to correctly construct the messages that can convince them.Gules (2002) claims that penetrating with the books, magazines etc. read by your target audience, and on the subjects they have knowledge about, and having information about them will provide the opportunity to think like them.

It is seen that the opinions of the participants are parallel to the ideas of the authors.

\subsection{Theme 3: Forum}

Participants $(1,4)$ state that the blogs, chat rooms, and forums frequented by the club supporters as their own places, and if a member of the club joins them will create the impression that they are valued. In addition, the participants state that active participation will be beneficial in order to present ideas, and recommendations on all issues about the club, and to receive opinions from the fans. Soylemez and Kayabası (2020) define forums as sites that exchange ideas, and information according to their special interests. Kocabas (2015) stated that businesses can attract the attention of special interest groups by participating in such formations or as a sponsor. Scott (2010) also stated that participants of discussion forums in which people have a common bond feel that the forums belong to them.

Participants $(1,2,5)$ state that club marketing unit staff should participate in online groups effectively. In addition, participants stated that posting messages in other places that would have less impact while there are online places to explain about the club's products, and 
services for sale will not meet the intended purpose. Kocabas (2015) claimed that the linking feature of the Internet will enable participants who see your posts in a forum or blog to reach there from other forums and blogs.

Participants $(1,2,4,5)$ say that purposeful people can easily attempt to spread false news where the forums are in order to put the sports club management in a difficult situation, and in such cases, it is necessary to intervene in the unfounded news in a timely manner. Kocabas (2015) claimed that it would be appropriate for an official to respond to negative discussions about the company in the forums, and claims that if this is not done, the truth of the news will be confirmed.

The ideas of the participants, and the ideas of the authors are parallel.

\subsection{Theme 4: Blog}

Respondents $(1,2,3)$ state that blogs have become the most important, and effective way for people to find you, thanks to the power of search engines. In addition, the participants state that the journalists will reach your opinions, and quote from you through the blog. Again, Participants think that anyone who creates a blog, and posts here regularly will generate feedback. Yavuz and Haseki (2012) define Blog as a web-based tool, which means weblog, as a tool for disseminating news and public relations with the target audience, emphasizing mutual interaction with target audiences. Close (2012) claimed that blog users generally post regular comments, and posts with text, graphics, videos, or links to other blogs, and websites, often posted in chronological order. Tyson (2012) claims that the power of weblogs enables millions of people to easily publish their thoughts, and comment on them for millions.

Participants $(2,4)$ state that the use of the blog has become important in terms of watching what millions of people in the area of interest of the fans, and club are saying about your club, and your products in the market you sell in. In addition, the participants express that these blogs can play a role such as understanding the perspectives of people who express their opinions and bringing different opinions to the center of the club. Scot (2010) claimed that organizations use blogs to understand what stakeholders are doing. In addition, the author stated that blog-to-blog marketing is one of the most exciting, and powerful ways to get others to tell your story for you, and reach your target audience instead of marketing units.

The opinions of the participants support the thoughts, and claims of the authors.

\subsection{Theme 5: Podcast}

Participants $(1,3,4)$ state that podcast has become a tool used to produce audio content, and this application is another example of radio broadcasting in the digital world. In addition, the participants say that because the Pod broadcast is on certain topics, it has reached a more effective position than radio, which functions as a general news channel. Gonenli and Hurmeric (2012) stated that Podcasting is a social media component that enables individuals to distribute digital voices over the internet via their computers or portable media. Akar (2010) claimed that they typically provide regular updates on their content for viewers such as pod casters and video bloggers to consume. 
Participants $(1,2)$ claim that the podcasts have become a suitable platform for the regular flow of information by the expert of the subject, with contents covering a series, and useful topics to reach the target audience by the club. In addition, the participants state that with content marketing that can be used in the marketing mix, preparing audio content that the fans who are in the purchasing plan want to listen to, may become the preferred choice. Rowles and Rogers (2015) claim that marketing professionals have a tool such as podcasting that they can effectively create audio content, and deliver it to those who want to buy it. The author also claims that Podcast has become an increasingly important part of the marketing mix as a component of a comprehensive content marketing strategy.

Participants $(1,5)$ state that podcasts are a suitable tool for content marketing that can be used in the marketing mix, and pod broadcasting can be prepared economically with some technological tools, and can contribute to the club's reaching a global position by expanding its communication field. Scott (2010) claims that it will be used as a compatible and affordable marketing strategy for many organizations with marketing podcasts, blog posts, a great website, e-books and other online marketing tools, and programs. Scott also explains that through podcasting, a large number of people can listen to the programs they choose according to their particular interests.

The thoughts of the participants are parallel to the claims of the authors.

\subsection{Theme 6: Press Release}

Participants $(1,4)$ state that press releases are a way of communicating with the target audience and that bulletins are an important tool to direct people to the sales process. In addition, the participants say that press members are an important complement to the marketing mix, and that thanks to the Internet, the target audience is not only fans, but also people who have internet connectivity, and use search engines together with journalists. Kelleher (2007) explained that online press releases can be a useful tool in spreading information to relevant target audiences. Scott (2010) stated that press releases targeting consumers directly are an important component of the marketing mix. In addition, the author stated that the media still obtains some of its content from press releases, and that millions of people read the press releases directly from the source without being filtered by the media.

Participants $(2,5)$ state that the message to be delivered will reach the party directly from its source without any change, thanks to the web-based internet. In addition, the participants say that most of the topics that the media report on today are from print bulletins. Scott (2010) claimed that it will be useful to create appropriate communication channels for the target audiences to react to the press releases, and to present the proposals that may be in their favor.

Participants $(1,4,5)$ state that press releases are an activity that improves relations with the public, and that the news flow should be improved with press releases in order to maintain this uninterruptedly. In addition, the participants say that it is necessary to produce rich content to meet the needs of the fans instead of making news that will be valuable for the press. Heath and Coombs (2006) along with their Web sites, claim that online press releases 
are one of the most used internet-based applications by public relations practitioners.

Participants $(1,2,5)$ state that the links of the places where the message links are located should be placed in appropriate places on the website in order to facilitate the access of the fans to the newsletters written by the club. Scott (2010) stated that it is necessary to optimize the word selection in press releases to be easily found in search engines, and that it is appropriate to add media tags to other famous sites.

The statements of the contributors support the authors' findings.

\subsection{Theme 7: E-Mail Groups}

Participants $(1,5)$ state that it is beneficial to use e-mail in order to send mass messages within the scope of marketing campaigns to the lists in the group prepared in accordance with the age, gender, education etc. category. Ryan (2016) stated that e-mails are mails that contain a sales text, and a call to action sent to the customer list of Businesses. The author also claims that it will be useful for the campaigns to get detailed information while registering the people on the mailing list to the database.

Participants $(1,5)$ say that it will be effective to make a separation into groups in the formation of the list (age, gender, city, etc.) of the target audience. Penpece (2013) declared that e-mail marketing should primarily create an e-commodity list-groups and prepare products, and campaigns in line with the requests, and needs of the customers in this list.

\subsection{Theme 8: Content Sharing Sites}

YouTube: Participants $(1,3)$ state that YouTube is an ideal place especially for video sharing and that every sports club can use it as a promotional tool and an advertisement place. In addition, the participants state that the YouTube channel, which can also be performed live, has an interactive environment, and is an ideal place to get the fans' opinions on certain issues. Participants $(2,4)$ state that YouTube can be easily used together with other social media applications. Sin, Nor, and Al-agaga (2012) claim that YouTube is a video sharing site that contains millions of videos, and that businesses can upload their own promotional videos, and broadcast their advertisements. In addition, the author defines YouTube, which can be used easily with other social media, as a social media tool where they can provide customer satisfaction, and loyalty by responding instantly according to the click-through rate, and comments and opinions.

Facebook: Participants $(1,3)$ state that Facebook is a very suitable area for advertising-promotion, and marketing and that event messages can be easily conveyed to the fans. In addition, the participants say that it is a suitable platform for the fans to get ideas on issues concerning the club. Kerpen (2011) stated that Facebook provides the opportunity to communicate, and connect with the target audience. In addition, the author claims that it has become the world's largest social network with the participation of nearly a million new people every day. Schmidt and Ralph (2011) state that Facebook is a social networking site that can be used in various ways as a marketing tool. The author also claims that companies can be friends with Facebook members, and send them a private message on any event or 
important topic.

LinkedIn: Participants $(2,5)$ point out that Linkedln will contribute to the promotion of the club, and that it is an area for human resources to send messages for job postings or sudden events. Yavuz and Haseki (2012) state that Linkedln is a place that can be preferred in terms of reflecting the potential of an individual or a business. Kerpen (2011) claims that although Linkedln is very advantageous when used effectively, it is necessary to work with the HR department for effective advertisement, and success of the company.

Twitter: Participants $(1,4)$ state that fans via Twitter are a suitable medium to be informed very quickly about the activities, products, services, and after-sales support activities of the clubs. Participants also state that this facility increases the traffic of marketing activities, and associated development activities. Altug and Ozhan (2018) claim that Twitter has the opportunity to market, strengthen the brand, establish new customers, and business connections, and follow popular topics, especially for businesses. Listening to the masses is an ideal method for two-way communication, content exchange, partnership formation, and maintenance, according to Yavuz and Haseki (2012).

\section{Suggestions}

The use of social media, public relations, and marketing - advertising in today's digitalized world has created an area that requires skill. It is becoming increasingly important for those working on these challenges to collaborate. Instead of functioning in a hierarchical structure on a vertical axis, I believe that sports clubs would benefit from transforming into a horizontal structure in order to grow.

To better understand the new trend marketing dynamics, it would be useful to undertake separate studies on each of the web-based technologies used across a large area.

\section{References}

Akar, E. (2010). Social Media Marketing: Marketing Strategies on Social Web, Ankara, Efil Publishing.

Argan, M., \& Katırc1, H. (2020). Sports Marketing (4th ed.). Nobel Publishing, Ankara.

Balta, P. F. (2012). Social Media Social Change, in Social Media Academy. Istanbul: Beta Publishing.

Constantinides, E. (2014). Foundations of Social Media Marketing, Procedia-Social and Behavioral Sciences, 148, 40-57. https://doi.org/10.1016/j.sbspro.2014.07.016

Evans, D. (2012). Social Media Marketing an Hour a Day (2nd ed.). Indiana, John Wiley \& Sons Inc.

Gonenli, G., \& Hurmeriç, P. (2012). Social Media: Using Facebook as a Field Study. Istanbul: Beta Publishing.

Gules, H. K., Bulbul, H., \& Çelebi, A. (2003). Electronic Commerce Applications in Small and Medium Industry Enterprises. Selçuk University Social Sciences Institute Journal, 9, 
$463-481$.

Heath, R. L., \& Coombs, W. T. (2006). Today's Public Relations: An Introduction. Thousand Oaks, CA: Sage Publications, Inc. https://doi.org/10.4135/9781452233055

Kaplan, A. M., \& Haenlein, M. (2010). Users of the word, Unite! The challenges and opportunuties of social media. Business Horizons, 53(1), 59-68. https://doi.org/10.1016/ j.bushor.2009.09.003

Kelleher, T. (2007). Public Relations Online: Lasting Concepts for Changing Media. Thousand Oaks, CA: Sage Publishing. https://doi.org/10.4135/9781452225876

Kerpen, D. (2011). Likeable Social Media: How to Delight Your Customers, Create an Irresistible Brand, and Be Generally Amazing on Facebook (\& Other Social Networks). McGraw Hill.

Kırcova, I., \& Enginkaya, E. (2015). Social Media Marketing. Beta Publishing, Istanbul.

Kietzmann, J., Mills, A. J., \& Plangger, K. (2020). Deepfakes: Perspectives on the future "reality" of advertising and branding. International Journal of Advertising, 40(3), 473-485. https://doi.org/10.1080/02650487.2020.1834211

Kocabaş, F. (2005). New Approaches in Marketing and Advertising. Donence Publishing, Istanbul.

Milletsky, J. I. (2009). Principles of internet marketing: New tools and methods for web developers. Course Technology.

Mullin, B., Hardy, S., \& Sutton, W. A. (1993). Sports Marketing. Human Kinetics Publishers.

Ozmen, S. (2003). New Trade Path in Network Economy: E-Commerce. Bilgi University Publications, Istanbul.

Ozturk, M. F., \& Talas, M. (2015). Social Media and Education Interaction. Journal of Word of Turks, 7(1), 101-120.

Parks, J. B., Zanger, B. R. K., \& Quarterman, J. (1998). Contemporary Sport Management (2nd ed.). Human Knetiks Publishers.

Pitts, B. G., \& Stotlar, D. K. (2013). Fundamental of Sports Marketing (4th ed.). Sport Management Library.

Plume, C. J., Dwivedi, Y. K., \& Slade, E. L. (2011). Social Media: More Available Marketing Tools.Business Success. New Jersey: John Wiley \& Sons Inc.

Pulizzi, J. (2013). Epic Content Marketing. McGraw-Hill Education.

Rowles, D., \& Rogers, C. (2015). Podcast broadcasting and Marketing. Eren Publishing, Istanbul.

Schmidt, S. M. P., \& Ralph, D. L. (2011). Social media: More available marketing tools. The Busines Review, 18(2), 37-43. 
Scott, D. M. (2010). New Rules of Marketing and Communication. Mediacat, Istanbul.

Sigala, M. (2016). Book review "Social media management: Technologies and strategies for creating business value", Amy van Looy. Information Technology \& Tourism, 17, 363-365. https://doi.org/10.1007/s40558-016-0062-3

Sin, S. S., Nor, K. M., \& Al-Agaga, A. M. (2012). Factors Affecting Malaysian Young Consumers' online purchase intention in social media websites. Procedia-Social and Behavioral Sciences, 40, 326-333. https://doi.org/10.1016/j.sbspro.2012.03.195

Stephen, A. (2016). The role of Digital, and Social Media Marketing in Consumer Behavior. Current Opinion in Psychology, 10, 17-21. https://doi.org/10.1016/j.copsyc.2015.10.016

Sultan, F., \& Rohm, A. J. (2004). The Evolving Role of the Internet in Marketing Strategy: An Exploratory Study. Journal of Interactive Marketing, 18(2), 6-19. https://doi.org/10.1002/ dir.20003

Tuten, T. L. (2008). Advertising 2.0: Social Media Marketing in a Web 2.0 World. United States of America: Preggers.

\section{Copyright Disclaimer}

Copyright for this article is retained by the author(s), with first publication rights granted to the journal.

This is an open-access article distributed under the terms and conditions of the Creative Commons Attribution license (http://creativecommons.org/licenses/by/3.0/). 